\title{
Fair Value of Biological Assets: An Interdisciplinary Methodological Proposal
}

\author{
Valor Justo de Ativos Biológicos: Uma Proposta Metodológica Interdisciplinar
}

\author{
Rafael Todescato Cavalheiro ${ }^{1}$ \\ (D) https://orcid.org/0000-0002-3468-5357 \\ Régio Marcio Toesca Gimenes ${ }^{1}$ \\ (D) https://orcid.org//0000-0001-7834-9892 \\ Erlaine Binotto ${ }^{1}$ \\ (D) https://orcid.org/0000-0002-0349-4566 \\ Carlos Ricardo Fietz ${ }^{2}$ \\ (iD) https://orcid.org/0000-0002-6153-7210
}

Universidade Federal da Grande Dourados, Faculdade de Administração, Ciências Contábeis e Economia, Dourados, MS, Brasil ${ }^{1}$ Empresa Brasileira de Pesquisa Agropecuária, Embrapa Agropecuária Oeste, Dourados, MS, Brasil²

Received 9 October 2018. Last version received at 8 February 2019. Accepted 11 February 2019. Editor-in-chief: Prof. Wesley Mendes-Da-Silva.

\# of invited reviewers until the decision

\begin{tabular}{lllllllll} 
& 1 & 2 & 3 & 4 & 5 & 6 & 7 & 8 \\
\hline 1st round & $\$$ & $\otimes$ & 5 & & & & \\
\hline 2nd round & $\$$ & & & & & & & \\
\hline
\end{tabular}




\title{
Resumo
}

Dada a complexidade de se mensurar o fair value de ativos biológicos agrícolas, que geralmente não possuem um mercado ativo e são dependentes de fatores climáticos, ambientais e biológicos, surge a necessidade de uma visão interdisciplinar que considere outros inputs além dos econômicos e contábeis. Nesse sentido, o presente ensaio teórico tem por objetivo propor uma metodologia interdisciplinar de mensuração do fair value de ativos biológicos agrícolas considerando também os fatores agronômicos. Como método, foi adotado a pesquisa bibliográfica de natureza exploratório-descritiva. Para sustentar a proposta metodológica interdisciplinar, um quadro teórico foi desenvolvido utilizando as lentes disciplinares da contabilidade, economia e agronomia, com enfoque na modelagem agrometeorológica. Além da proposição metodológica, foi realizada uma aplicação no setor sucroenergético para demonstrar o comportamento e alcance das variáveis. A principal contribuição deste estudo reside na proposição de uma metodologia de mensuração inovadora, que considera os aspectos agronômicos na mensuração contábil, podendo resultar em melhoria na qualidade da informação, principalmente, quanto a fidedignidade.

Palavras-chave: valor justo; ativo biológico; interdisciplinaridade.

\begin{abstract}
Given the complexity of measuring the fair value of agricultural biological assets, which generally do not have an active market and are dependent on climatic, environmental and biological factors, there is a need for an interdisciplinary view that considers inputs other than economic and accounting. In this sense, the present theoretical essay aims to propose an interdisciplinary methodology to measure the fair value of agricultural biological assets considering also the agronomic factors. As a method, a bibliographic research of an exploratorydescriptive nature was adopted. To support the interdisciplinary methodological proposal, a theoretical framework was developed using the disciplinary lenses of accounting, economics and agronomy, with a focus on agrometeorological modeling. In addition to the methodological proposition, an application was made in the sugarcane sector to demonstrate the behavior and range of the variables. The main contribution of this study is the proposition of an innovative measurement methodology, which considers the agronomic aspects in accounting measurement, which can result in an improvement in the quality of the information, mainly as regards reliability.
\end{abstract}

Keywords: fair value; biological asset; interdisciplinarity.

JEL Code: O32, Q16, C18. 


\section{Introdução}

The traditional bases of knowledge of an academic discipline can be potentially affected by changes in business and professional activities, mainly by technological development, the emergence of new management tools and analysis, as well as the intensification of competition in the complex business environment (Miller, 2002). Starting in the 1950s, changes in business practices began to reflect exponentially in accounting, which began to be influenced by various disciplines, such as economics, administration, psychology, among others (Most, 1977).

The importance of interdisciplinary links is revealed throughout the history of accounting (Walker, 2005), which directly indicates, in a general way, the degree of development of organizations and societies as a science of wealth control (Holanda, 2001). However, even with the strong influence of positive accounting theory, efforts are still needed from a social and political perspective, so that accounting science incorporates the lens of other sciences and better understands equity and society, focusing on the good of society (Malsch \& Guénin-Paracini, 2013).

The science of accounting has undergone many changes following the International Financial Reporting Standards (IFRS), which makes it based on principles rather than detailed rules (Lopes, Galdi, \& Lima, 2011). These changes also led to the accounting of the agribusiness sector through IAS 41 Agriculture, which establishes the accounting treatment and the respective disclosures on biological assets and agricultural products.

Under IAS 41, biological assets and agricultural products are measured at fair value rather than historical cost. Since fair value "is the price that would be received to sell an asset or paid to transfer a liability in an orderly transaction between market participants at the measurement date" (IFRS, 2011, p. 2 ), it can be considered the meeting point of interests between the buyer and the seller (Iudícibus \& Martins, 2007) and, therefore, it meets the fundamental qualitative characteristics of the accounting information: relevance and faithful representation.

Proponents of fair value measurement argue that this basis of assessment increases the relevanceu of accounting information, as it better reflects the economic-financial reality of entities (Argilés-Bosch, Bladon, \& Monllau, 2009; Argilés-Bosch, Miarons, Garcia-Blandon, Benavente, \& Ravenda, 2018; Armstrong, Barth, Jagolinzer, \& Riedl, 2010; Barth, 2006; Barth, Landsman, \& Lang, 2008; Elad \& Herbohn, 2011; Gonçalves, Lopes, \& Craig, 2017; Hinke \& Stárová, 2013). However, biological assets that are not attached to an active market requires an appraiser's judgment on a range of accounting choices for their valuation that can affect the reliability of the information (Bohušová, Svoboda, \& Nerudová, 2012; Kallapur \& Kwan, 2004; Yang, Rohrbach, \& Chen, 2005).

In general, the valuation of biological assets that are not attached to an active market is performed at level three of the fair value hierarchy and is based on asset pricing techniques, such as Discounted Cash Flow (DCF) (Rech \& Oliveira, 2011; Ribeiro, 2013; Santos, Gomes, Brito, Gaio, \& Furlan, 2015). This technique is based on the estimation of quantity and price of sale, costs and expenses, depreciation, discount rate and period of projection of cash flows, and involves a series of accounting choices for adequate measurement of biological assets.

The fragmented view of attributes relevant to assessing biological assets does not allow for a comprehensive measure of their value (Morin, 2007), so a more systemic view to bridging across disciplines becomes important (Buanes \& Jentoft, 2009). Such a view would allow the approach of the object of study from an interdisciplinary perspective, considering not only the accounting and economic aspects, but also the agronomic aspects that quantitatively and qualitatively alter the value of biological assets.

In this context, the question that guides this theoretical essay is: how to measure the fair value of agricultural biological assets without an active market in an interdisciplinary perspective? Therefore, 
the overall objective of this essay is to propose an interdisciplinary methodology for measuring the fair value of agricultural biological assets without an active market.

As a method, this theoretical essay used an exploratory-descriptive bibliographical research, which initially presents an overview of accounting and interdisciplinarity and fair value of biological assets. In sequence, a theoretical framework is presented using the disciplinary lenses of accounting and economics, considering the DCF and its variables as a measurement technique. The disciplinary lens of agronomy is presented to demonstrate the potential of agrometeorological modeling for measuring biological assets. Finally, an interdisciplinary method integrating the accounting, economic and agronomic variables is proposed as a measurement of the fair value of agricultural biological assets without active market.

Due to the contemporaneous nature of the subject and to the small number of studies available in the literature, it is expected that this essay contributes to the understanding of fair value measurement in the context of biological assets without active market, as well as for their empirical application. It should be emphasized that the interdisciplinary approach proposed here goes beyond accounting and economic techniques considered by the market and the academy, since it also involves agronomic aspects.

The aggregation of agronomic science can contribute significantly to the measurement of the fair value of biological assets by minimizing overestimation or underestimation of the economic value of the asset. When climate, environmental and biological risks are considered, the quality of accounting information is increased, especially faithful representation, since such variables are included in the estimation of productivity by agrometeorological modeling.

\section{Accounting and Interdisciplinarity}

Interdisciplinarity is generally understood as the appropriate combination of knowledge from various disciplines (Brewer, 1999) or it can be broadly represented as the integration of knowledge from different disciplinary points of view, in order to unfold insights inaccessible to both emerging issues and problems previously addressed (Stember, 1991). The interdisciplinary approach embraces multiple focuses of analysis, across multiple social, institutional, cultural, political, legal and technological contexts, and contrasts with the emphasis of dominant quantitative positivist research (Brewer, 1999).

According to Roslender and Dillard (2003), in accounting, interdisciplinarity represents the other, that is, all other disciplines outside the economy: history, philosophy, political science, social psychology, sociology, organizational behavior, etc. Parker (2012) points out that interdisciplinary accounting researchers often embrace the complexity of the whole in search of understandings, perceptions, criticisms, and holistic contributions, rather than seeking abstract deductive simplifications.

Based on multiple perspectives outside the accounting discipline, it is possible to expand and deepen the skills of accounting researchers (Hansson, 1999), who consider accounting as an active and reflective driver of change (Roslender \& Dillard, 2003). Considering that, interdisciplinary studies challenge the hegemony of existing models and judgments and allow us to see what was previously invisible or latent, "it is as if we have been equipped with new lenses" (Fogarty, 2014, p. 1266). Expanding the theoretical and methodological repertoire of accounting studies offers more room for diversity and greater range of accounting, considering the complex business environment and the demand of a wide range of stakeholders (Ahrens et al., 2008; Davila \& Oyon, 2008).

Using the new lenses mentioned by Fogarty (2014), this essay proposes to analyze the mandatory context of the measurement of the fair value of biological assets in an interdisciplinary perspective, trying to deal holistically with the complex interrelations that characterize the accounting process and its environment (Stember, 1991), focusing on proposing a measurement methodology that can contribute to society, as warned by Hopwood (2008). 


\section{Fair Value of Biological Assets}

The main change that came with IAS 41 is the obligation to measure biological assets at fair value, abandoning the concept of historical cost, most of the time. Prior to the approval of the standard, biological assets were generally measured at historical cost or at formation cost. However, agricultural products were already valued at fair value or historical cost, depending on the accounting standards of each country (Elad \& Herbohn, 2011).

According to Lipe (2002), fair value under normal market conditions is a well-defined measure of value, and there is no significant question as to its relevance and credibility. However, there is not always an active market with available information or observable transactions, especially for the specificities of biological assets.

To increase the consistency and comparability of fair value measurements and improve the dissemination of valuation criteria, the International Accounting Standards Board (IASB) created the IFRS 13, thereby establishing a fair value hierarchy. This three-level hierarchy classifies the inputs applied to the assessment techniques.

Level one inputs are the active market information that represents the most reliable evidence of fair value and should be used whenever possible without any adjustment. Level two inputs are the quoted prices for identical or similar assets in active markets that are directly or indirectly observable and include information corroborated by the market. And level three inputs involve the use of unobservable data, based on assumptions that market participants would use to price the asset, including assumptions about risk (IFRS, 2011).

Under IFRS 13, companies should develop unobservable data from the best information available at the time of the valuation, including entity data. When unobservable data are developed in accordance with IFRS, they become the premises of market participants and meet the objective of measuring fair value (IFRS, 2011).

When there is no active market, that is, the measurement Poon is performed at level two or three of the fair value hierarchy, the accounting professional is required to have a certain degree of judgment, which may impact on the reliability and relevance of the information generated (Poon, 2004; Yang et al., 2005), in addition to provide managers with more opportunities to manage results (Eckel, Fortin, \& Fisher, 2003; Herbohn \& Herbohn, 2006; Rathke, Santana, Lourenço, \& Dalmácio, 2016; R. L. M. da Silva, Nardi, \& Ribeiro, 2015; Watts, 2003).

However, when the market is not efficient, the asset price determined by this market may not represent the fair value. According to Martins (2002) the inputs used in the formation of the price may be biased by both the seller and the buyer. In such cases, the present value of future cash flows should be used as an estimate of fair value (Martins, 2002).

As this essay aims to propose an interdisciplinary methodology for measuring the fair value of biological assets, the theoretical basis for the proposal will be addressed in the next sessions, initially using the disciplinary lenses of accounting and economics.

\section{Using the Disciplinary Lenses of Accounting and Economics}

The central point of accounting measurement is the establishment of a measure that brings the accounting information generated from the economic reality of equity to the maximum. In accounting, measurement "is the process of allocation of significant monetary values to objects or events associated with a company and obtained to allow aggregation or disaggregation, when required in specific 
situations" (Hendriksen \& Van Breda, 2015, p. 304). Intense discussions arise in the face of the various asset valuation methods that accounting professionals adopt (Iudícibus, 2010).

Discounted cash flow is a measurement method that makes it possible to demonstrate the actual ability to generate wealth from a business or asset and can be considered as one of the most complete methods for pricing assets (Póvoa, 2007). This method is based "on the 'present value' rule, where the value of any asset is the present value of its expected future cash flows" (Damodaran, 2010, p. 12), that is, the present value is determined by the amount that enters and leaves the cash, discounted at an appropriate rate.

According to Hendriksen and Van Breda (2015), the net present value of a company or an asset can be obtained by the following equation.

$$
\mathrm{VT}_{\mathrm{j}}=\sum_{\mathrm{j}=1}^{\infty} \frac{\mathrm{FCF}_{\mathrm{j}}}{(1+\mathrm{r})^{\mathrm{j}}}
$$

Where:

$\mathrm{VT}_{\mathrm{j}}=$ value of the company at time $\mathrm{j}$

$\mathrm{FCF}_{\mathrm{j}}=$ free cash flow during the period $\mathrm{j}$

$r=$ market interest rate or opportunity cost

$\mathrm{j}=$ projection period

Note that Equation 1 represents the discounted cash flow model for the measurement of the value of a company, however, when using this equation for the measurement of isolated assets, it is considered only the expected cash flow of the evaluated asset in the $\mathrm{FCF}_{\mathrm{j}}$ variable.

The starting point for the preparation of the cash flow is the determination of the Operational Cash Flow (OCF), since the value of an asset is obtained by discounting the cash flows expected for it, that is, "cash flows cash residual after realizing all operating expenses and taxes, but before paying the debts, by the weighted average cost of capital" (Martelanc, Pasin, \& Pereira, 2010, p. 19). Barth, Cram and Nelson (2001) argue that the OCF is the best predictor of future cash flows. One of the accounting choices regarding the measurement of an asset lies at this point, since the variable $\mathrm{FCF}_{\mathrm{j}}$ represents the expected cash flow for year $\mathrm{j}$, and the way this information is generated implies differences in the value of the asset.

Without much questioning, the projection period of cash flows is the period in which future economic benefits are expected. However, the definition of the discount rate essentially depends on the risk estimates inherent in the assets evaluated to represent the appropriate market rate, and therefore are difficult to establish (Hendriksen \& Van Breda, 2015).

The role of the discount rate is to translate the expected value of cash flows into present value (Copeland, Koller, \& Murrin, 2002; Damodaran, 2009; Ross, Westerfield, \& Jaffe, 1997/2002), and this justifies its importance, difficulty of obtaining and not unanimity among those responsible for the measurement of assets. This rate is considered by Póvoa (2007) as one of the most important estimates in the calculation of the present value of cash flows.

According to Damodaran (2007, p. 19) "in discounted cash flow assessments, discount rates should reflect the degree of risk of cash flows" and can be understood as the minimum return required to attract investments (Hendriksen \& Van Breda, 2015). Among the more discount rates used by the market, the Capital Asset Pricing Model (CAPM) and the Weighted Average Cost of Capital (WACC) model are worth mentioning.

The CAPM model allows calculating the cost of equity (Copeland et al., 2002). In the CAPM model the expected return on an asset is equal to the return on a risk free title plus systematic risk (beta) 
multiplied by the difference between the expected return on a market portfolio and the return on a risk free title (Hendriksen \& Van Breda, 2015).

The CAPM model has received much criticism from academia because of insufficient conditions or unreached premises to valid the model. The model considers perfect competition, zero transaction costs, risk aversion, identical beliefs and prospects of investors, and the normal distribution of title returns (Damodaran, 2007; Hendriksen \& Van Breda, 2015). The difficulties of applying CAPM in emerging markets lie in its own premises, since the market efficiency condition is not usually met in these markets.

From the original model, several models were developed focusing on emerging market particularities, such as the Adjusted Hybrid CAPM (AH-CAPM) proposed by Pereiro (2001). Emerging market volatility makes data unstable, making it difficult to measure betas and premiums for market risk and resulting in a loss of reliability of the information generated on the basis of these data (Pereiro, 2001).

To minimize these problems, Pereiro (2001) proposed the AH-CAPM model, which uses global and local market data, as presented in the following equation.

$$
K_{e}=R f_{g}+R_{c}+\beta C_{L G}\left[\beta_{G G}\left(R_{M G}-R f_{g}\right)\right]\left(1-R^{2}\right)
$$

Where:

$$
\begin{aligned}
& K e=\text { cost of equity } \\
& R f_{g}=\text { global risk-free rate } \\
& R_{C}=\text { country risk premium } \\
& \beta C_{L G}=\text { country Beta } \\
& \beta_{G G}=\text { average unlevered Beta of comparable companies quoting in the global market } \\
& R_{M G}=\text { global market return } \\
& R^{2}=\text { coefficient of determination of the regression between the equity volatility of the domestic } \\
& \quad \text { market against the variation in country risk }
\end{aligned}
$$

The AH-CAPM model "adjusts global market premium to local market using a country Beta that mathematically represents the slope of the regression between the local market and the global market indexes" (Teixeira \& Cunha, 2017, p. 5). According to Pereiro (2001), the advantage of this model is the simplified inclusion of global market data. However, the model assumes that there is stability between global and local betas, and this impacts the results.

Given the company's ability to finance both equity and third-party capital, the discount rate suggested for this case is WACC (Ross et al., 1997/2002). "WACC is the discount rate applied to the expected future cash flows available to the company to determine its fair value" (Assaf Neto, 2017, p. 96), which is determined by Equation 3.

$$
W A C C=\left[\mathrm{k}_{e}\left(\frac{P L}{(P+P L)}\right)\right]+\left[\left(k_{i}(1-\mathrm{T})\right)\left(\frac{P}{(P+P L)}\right)\right]
$$

Where:

$$
\begin{aligned}
& K_{e}=\text { cost of equity } \\
& K_{i}=\text { cost of third-party capital } \\
& T=\text { corporate income tax rate } \\
& P=\text { value of the firm's debt }
\end{aligned}
$$




$$
\begin{aligned}
& P L=\text { value of the firm's equity } \\
& (P+P L)=\text { total value of the firm's financing (equity and debt). }
\end{aligned}
$$

According to Assaf Neto (2017), WACC is determined by the economic risk of a company's investment, by choosing the type of capital that minimizes financial risks and by the cost of external financing. This rate measures the cost of equity and third parties; therefore, it is equivalent to the discount rate of the operating cash flows and represents the total cost of capital of the company.

This session addressed the theoretical and accounting bases that will subsidize the interdisciplinary methodological proposal, considering the measurement of the fair value of biological assets without an active market. For a genuinely interdisciplinary proposal, it is necessary to incorporate other disciplines, as mentioned by Roslender and Dillard (2003). Accordingly, the next session addresses some of the contributions that agronomy can make to agribusiness accounting.

\section{Using the Disciplinary Lenses of Agronomy}

Knowledge about plant growth needs to be incorporated into economic studies related to agricultural production processes (Chavas, Kliebenstein, \& Crenshaw, 1985), because agronomy can provide very useful information about these biological assets, which are dynamic in nature (Chavas, Chambers, \& Pope, 2010). Among these information, we highlight the productivity estimates of the agricultural crops, which are strategic for the producers, as well as for the country (L. L. Silva, Costa, Campos, \& Dantas, 2009).

Productivity estimates are generally based on agrometeorological modeling, which is based on the statistical relationship between dependent variables and independent agrometeorological variables. Agrometeorological models are needed to predict the productivity of a crop under certain climatic, cropping and management conditions and are particularly important in agricultural production analyzes when water is scarce (Doorenbos \& Kassam, 1979).

According to S. A. Silva, Lima and Oliveira (2011), the mathematical models of agrometeorological monitoring consider that each climatic element exerts some influence on crop productivity, interfering as a factor of efficiency in its performance. According to Monteiro (2009, p. 2), "during its productive cycle, the plant responds directly to the meteorological conditions, which form a combination of factors whose effects can range from the most favorable to the most unfavorable to its growth and productivity".

In addition to agrometeorological models contributing to the prediction of agricultural crops, they also subsidize decision-making in terms of identifying factors that negatively affect productivity throughout the crop cycle (Rosa, Moreira, Rudorff, \& Adami, 2010) and its use is essential for a sustainable agriculture (Sivakumar, Gommes, \& Baier, 2000). Therefore, agrometeorological models allow the agricultural sector to make important decisions, improve land use planning, adapt crops, monitor and forecast harvests, control pests and diseases, and so on.

\section{Agrometeorological models for estimating agricultural productivity}

The maximum yield of the plant, also known as potential productivity (PP), is established by genetic characteristics and degree of adaptation of the crop to the environment (A. R. Pereira, Angelocci, \& Sentelhas, 2002). The PP represents a crop's ability to transform solar energy and CO2 into dry matter, that is, agricultural produce (A. R. Pereira et al., 2002). Knowing the plant's maximum yield allows the identification of productive potential in different areas and the adequacy of crops for a given region (Marin, Sentelhas, \& Ungaro, 2000). 
Climate variations expose agricultural activities to risks and failures (Dantas, Carvalho, \& Ferreira, 2007). In this context, soil conditions, solar radiation, and mainly water availability are factors that significantly interfere with photosynthesis (Ashraf \& Foolad, 2007; Pegorare, Fedatto, Pereira, Souza, \& Fietz, 2009). Given the importance of water for agriculture, monitoring soil water conditions and the effects of water deficit on crops have been the focus of agronomic research at both the national and international levels.

Among other methods, the climatological water balance developed by Thornthwaite and Mather (1955) has been commonly used to monitor soil water conditions. The water balance accounts for water gains and losses of cultivated soil, allowing soil moisture management and water availability to develop crops in a given period (Empresa Brasileira de Pesquisa Agropecuária [EMBRAPA], Guia Clima, n.d.). "For the water balance, the maximum water storage in the soil (Available Water Capacity [AWC]) is defined, the total rainfall is measured and potential evapotranspiration is estimated for each period" (A. R. Pereira, 2005, p. 311).

Evapotranspiration, deficiency, surplus and storage of water in the soil can be estimated by the water balance (A. R. Pereira, Sediyama, \& Villa Nova, 1997). According to the authors, evapotranspiration represents the soil response to maintain water conditions ideal for crop growth and production. The crop's evapotranspiration $\left(E T_{c}\right)$ is taken to calculate the water balance to identify water deficiencies and possible yield losses (A. R. Pereira et al., 2002).

When the crop's water needs are fully met, the real evapotranspiration $\left(E T_{c}\right)$ is equal to the crop's evapotranspiration $\left(E T_{c}\right)$ (Oliveira, Santos, Ribeiro, Zolnier, \& Barbosa, 2012). However, when these needs are not fully met, crop productivity drops, indicating that the plants did not reach their maximum production potential due to water deficit.

The crop's genotype and phenological stage determine the impact that the water deficit will have on its growth and productivity (Doorenbos \& Kassam, 1979). These different responses to water deficit are represented by the coefficient of responsiveness to the water deficit $\left(K_{y}\right)$. Preferably, $K_{y}$ is determined under local conditions due to its relation to the particularities of the environmental factors (Kaboosi \& Kaveh, 2010).

Equation 4, proposed- by Doorenbos and Kassam (1979) in FAO Bulletin 33, predicts that crop productivity is directly related to water deficit, that is, the real productivity of a crop $\left(Y_{r}\right)$ is a result of the potential productivity $\left(Y_{m}\right)$ penalized by water stress and obtained by the factor $\left(1-\frac{E T_{r}}{E T_{m}}\right)$ as a function of its responsiveness to the water deficit $\left(K_{y}\right)$ (Oliveira et al., 2012).

$$
\left(1-\frac{Y_{r}}{Y_{m}}\right)=K_{y} \times\left(1-\frac{E T_{r}}{E T_{m}}\right)
$$

Where:

$Y_{r}=$ real productivity of the crop $\left(\mathrm{kg} \mathrm{ha}^{-1}\right)$

$Y_{m}=$ maximum potential productivity $\left(\mathrm{kg} \mathrm{ha}^{-1}\right)$

$K_{y}=$ coefficient of responsiveness to the water deficit (dimensionless)

$E T_{r}=$ real total cycle evapotranspiration $(\mathrm{mm})$

$E T_{m}=$ maximum total cycle evapotranspiration $(\mathrm{mm})$

For highly accurate agricultural forecasts, the productivity estimate by agrometeorological models implicitly or explicitly considers agricultural efficiency factors, such as amount of rainfall, solar radiation, temperature, wind speed, soil type, soil water conditions and specificities of the crops (Gouvêa, Sentelhas, Gazzola, \& Santos, 2009; Marin, Lopes-Assad, Assad, Vian, \& Santos, 2008), thus making agricultural projects more reliable (Hammer, Carberry, \& Stone, 2000). 
Agrometeorology projections can contribute significantly to the estimation of the fair value of biological assets. From them, future scenarios are anticipated, with the complexities and climate risks that directly affect the value of biological assets. According to Dias and Machado (2017), only inspired researchers intends to anticipate future scenarios. This being our purpose, we reinforce them with the interdisciplinary triangulation proposed below.

\section{Interdisciplinary Methodological Proposal for the Measurement of Agricultural Biological Assets}

Given the complexity of measuring agricultural biological assets without an active market, this article proposes, in a normative perspective, a triangulation between disciplines of accounting, economics and agronomy, using the DCF presented in Equation 1 - one of the most complete methods for measuring assets (Póvoa, 2007).

This assay was based on the guidance of IFRS 13 that companies should develop unobservable data using the best information available at the time of asset valuation. The assay preferably considers the present value of future cash flows as an estimate of the fair value of biological assets since the Brazilian market is not efficient. OCF was chosen as the best predictor of future cash flows, as indicated by Barth et al. (2001). To elaborate the OCF, all variables necessary to estimate the fair value must be collected. Some of them will be discussed below.

The variable $V T_{j}$ was renamed to $V A T_{j}$ to represent the biological asset value at time $j$. The principal variable of this methodological proposal is $O C F_{j}$, which is represented by the projected average price multiplied by the estimated value of the agrometeorological model with deduction of taxes, production costs and operating expenses of the asset development period. The variable $r$ is represented by WACC, the cost of capital being represented by the AH-CAPM Model and the cost of third-party capital being the weighted cost of debt, free of tax benefit. To better demonstrate the proposal, the are detailed in Table 1.

Table 1

Detail of the Components of the Measurement Methodology

\begin{tabular}{|c|c|c|c|}
\hline Element & Variables & Description & Discipline \\
\hline \multirow{7}{*}{ 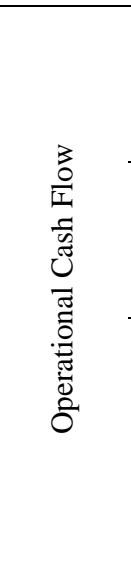 } & $\left(\frac{\sum_{n}^{1} P_{n}}{n}\right)$ & $\begin{array}{l}\text { Average price projected by regression, from } \\
n \text { available future prices }\end{array}$ & 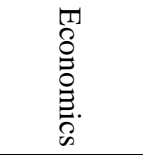 \\
\hline & $\left(\frac{\sum_{n \text { scenarios }}^{1}\left[1-K_{y}\left(1-\frac{E T_{r}}{E T_{m}}\right)\right] Y_{m}}{n \text { scenarios }}\right)$ & $\begin{array}{l}\text { Quantity projected from } n \text { designed } \\
\text { agrometeorological scenarios }\end{array}$ & 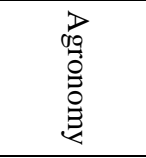 \\
\hline & $T B$ & Taxes on Projected Revenue & \multirow{5}{*}{ 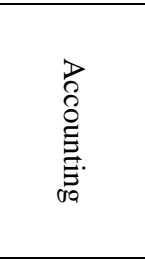 } \\
\hline & $C P P$ & Estimated Production Costs for the Period & \\
\hline & DO & Estimated Operating Expenses & \\
\hline & $D E_{x}$ & Estimated Depreciation & \\
\hline & $I R$ & Taxes on Profit & \\
\hline \multirow{5}{*}{ 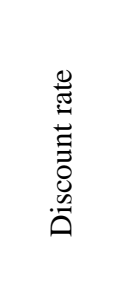 } & $\left\{R f_{g}+R_{c}+\beta C_{L G}\left[\beta_{G G}\left(R_{M G}-R f_{g}\right)\right]\left(1-R^{2}\right)\right\}$ & Cost of Equity $\left(K_{e}\right)$ & \multirow{5}{*}{ 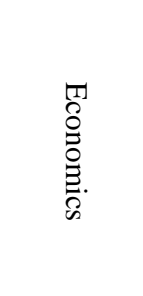 } \\
\hline & $k_{d}(1-T)$ & Cost of Debit $\left(K_{i}\right)$ & \\
\hline & $P$ & Debt & \\
\hline & $P L$ & Equity & \\
\hline & {$\left[k_{e}\left(\frac{P L}{(P+P L)}\right)\right]+\left[\left(k_{i}(1-I R)\right)\left(\frac{P}{(P+P L)}\right)\right]$} & Weighted Average Cost of Capital (WACC) & \\
\hline
\end{tabular}


Equation 5 represents mathematically the interdisciplinary methodological proposal for the valuation of agricultural biological assets without active market.

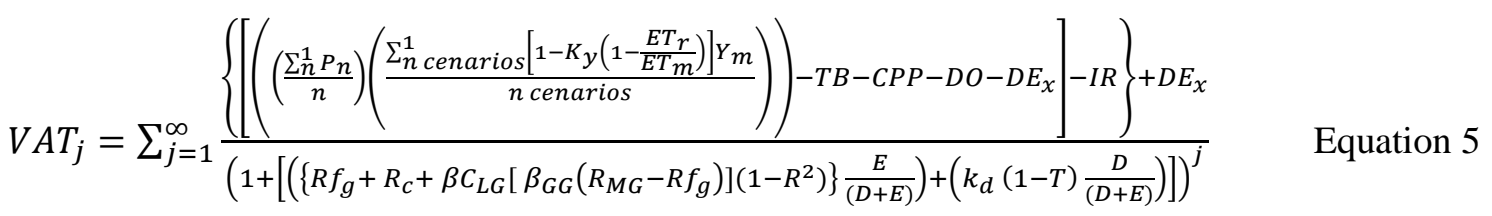

Where:

$V A T_{j}=$ value of the biological asset at time $j$

$$
O C F_{j}=\left\{\left[\left(\left(\frac{\sum_{n}^{1} P_{n}}{n}\right)\left(\frac{\sum_{n \text { cenarios }}^{1}\left[1-K_{y}\left(1-\frac{E T_{r}}{E T_{m}}\right)\right] Y_{m}}{n \text { cenarios }}\right)\right)-T B-C P P-D A O-D E_{x}\right]-I R\right\}+D E_{x}=
$$

operating cash flow of the asset at time $j$

$r=\left(1+\left[\left(\left\{R f_{g}+R_{c}+\beta C_{L G}\left[\beta_{G G}\left(R_{M G}-R f_{g}\right)\right]\left(1-\mathrm{R}^{2}\right)\right\} \frac{\mathrm{E}}{(\mathrm{D}+\mathrm{E})}\right)+\left(\mathrm{k}_{\mathrm{d}}(1-\mathrm{T}) \frac{\mathrm{D}}{(\mathrm{D}+\mathrm{E})}\right)\right]\right)=$ discount rate or opportunity cost

$\mathrm{j}=$ Projection period

The first variable is the projected price of the harvested agricultural product. Because it is generally volatile, price projection becomes complex. Therefore, it is necessary to identify the existence of a functional relationship between the price of the harvested agricultural product with other variables that theoretically can influence that price. Thus, a multiple regression is suggested considering the particularities and possible relations with other products that have future price quotations, such as sugarcane, whose ethanol and sugar prices are traded in the future market. Observable inputs are suggested for this regression, obtained from market data from autarchic sources, such as BM\&FBovespa, Centro de Pesquisas Econômicas da Escola Superior de Agricultura Luiz de Queiroz da Universidade de São Paulo (CEPEA/ESALQ-USP), among others. Projections can be made after identifying the functional relationship of the price with the variables analyzed and then the calculation of the average price to be used in the measurement of the biological asset.

The second variable is quantity, which is determinant in the measurement of biological assets, since it directly affects the projection of revenue. It is noted that both academics and market professionals have not given due attention to this variable, usually using historical averages of productivity. According to Hendriksen and Van Breda (2015), measurements based on past estimates should be reviewed and adjusted as new and more reliable estimates become available. In this context, several questions arise regarding the use of the historical average of productivity, mainly agronomic information.

Each climatic element exerts some control on the productivity of biological assets. Soil conditions, solar radiation and water availability are factors that directly interfere with crop performance (S. A. Silva, Lima, \& Oliveira, 2011). Therefore, discrediting them for productivity projections and hence for accounting measurements is quite unreasonable. This is one of the main challenge of this essay: enabling a productivity estimation considering the uncertainties of agriculture and using the agrometeorological model proposed by Doorenbos and Kassam (1979) combined with the construction of scenarios based on water deficit. It is important to consider these variations in productivity projections, resulting in more accurate agricultural forecasts (Gouvêa et al., 2009; Marin et al., 2008).

Public databases such as the EMBRAPA Climate Guide (EMBRAPA, Guia Clima, n.d.) are used to identify the maximum and real evapotranspiration of biological assets and theoretical data such as Doorenbos and Kassam (1979) are used to obtain the maximum productivity and $\mathrm{K}_{\mathrm{y}}$. In agrometeorological modeling, the use of a crop's responsiveness coefficient $\left(\mathrm{K}_{\mathrm{y}}\right)$ is important to project productivity as function of climatic and environmental factors. Doorenbos and Kassam (1979) introduce 
an averaged $\mathrm{K}_{\mathrm{y}}$ from several crops, which has been extensively used to estimate productivity at global level. It is worth mentioning that local environmental factors should be always considered for the local agricultural risk, as suggested by Kaboosi e Kaveh (2010). Together with the necessary elements for the agrometeorological modeling, agroclimatic scenarios are designed considering their probability of occurrence, or even, the use of the averaged productivity estimated by the projected scenarios. Thus, refined information is provided for accounting measurement, which focuses on the future expectation of productivity, contributing to the improvement of the information generated. Our agrometeorological modeling proposal also suggests the strategic participation of agronomy professionals, so that the measurement is more precise and consequently more relevant for stakeholders.

There is no news about the costs, operating expenses and depreciation used in the projection of cash flows. These variables are unobservable inputs estimated internally by the company, considered as the best information available at the time of valuation of the asset.

This essay integrates the WACC and AH-CAPM models for discount rates to improve the measurement of biological assets. The objective is to discount operating cash flows at a rate that represents the opportunity cost of investors in the context of an emerging country. This integration is an important contribution of this study, given the many criticisms that the CAPM model has received, mainly because Brazil is a country without market efficiency.

It is important to use verifiable inputs on the AH-CAPM model to increase the relevance of the information generated. Mainly when using representative global indices for emerging markets. We suggest the use of T-bond as a global risk-free rate, since national indices such as the Selic rate have little validity due to its high variability and its application for valuating companies and assets is questionable in the Brazilian context (Assaf Neto, Lima, \& Araújo, 2008). Another recommendation is the adoption of the MSCI ACWI Index adapted to encompass developed and emerging countries, generating a beta and a global market return that represents the global economic environment in a more comprehensive way, not targeted only to mature markets.

After identifying all the variables and elements, crops can be measured by the proposed methodology that assesses the fair value of the biological asset in an interdisciplinary way and in accordance with IAS 41. Meeting the IAS 41 standards, we suggest the measurement of the plant if applicable, considering it as an item of the property. The historical cost method is the most appropriate to measure this type of asset, as suggested by Svoboda and Bohušová (2017). Treating and detailing the variables used in the cash flow helps to reduce distortions in the measurement of the asset, and consequently of the equity.

\section{Application of the Interdisciplinary Methodology in the Sugarcane Sector}

In order to demonstrate the applicability of the proposed methodology, a simulation was carried out in a sugarcane agroindustry located in the southern region of the state of Mato Grosso do Sul. This agroindustry is a family business, organized as a limited liability company and opting for Real Income. Due to its agricultural activity, it has suspended the contributions of the Social Integration Program (PIS) and Contribution for Social Security Financing (COFINS) and has the deferred Tax on the Circulation of Merchandise and Services (ICMS) in accordance with State Decree (Decreto ${ }^{\circ}$ 9.895, 2000).

The company has an area of 6,500 hectares (ha) cultivated with sugarcane that produces agricultural products under development (cane standing), which will be marketed as final product for sugarcane plants. The 6,500 ha of sugar cane are distributed in 5 cuts, being the 1st cut 2,000 ha, 2nd cut 2,500 ha, 3rd cut 800 ha, 4th cut 700 ha and 5th cut 500 ha. Planting occurs between the months of December to April, and the harvest is full mechanized. The cultivar used by the company under study is RB867515. For the application of Equation 5, the accounting choices for the measurement of the sugarcane crop are presented in Table 2. 
Table 2

\title{
Detail of the Accounting Choices for the Application of the Methodology
}

$\frac{\text { Variables }}{\left(\frac{\sum_{n}^{1} P_{n}}{n}\right)}$

\author{
Accounting choices for the measurement and techniques
}

A linear regression was performed considering the price of the ton of sugarcane (TC) published by Secretaria de Estado de Meio Ambiente e Desenvolvimento Econômico do Mato Grosso do Sul (SEMADE, n.d.) with the price of hydrated ethanol published by CEPEA/ESALQ-USP (n.d.) for the period from 2003 to 2016, resulting in the model $y=46.462 x-0.797$, which presented a coefficient of determination $\mathrm{R}^{2}$ of 0.9590 . For price projection, the prices of hydrated alcohol $(\mathrm{n}=$ 10) traded on BM\&Fbovespa were used up to $31 / 01 / 2019$. Therefore, the sale price of TC used in this study is R \$ 71.08, higher than the historical average of R \$ 65.63 , already deflated by the General Price Index - Market (IGP-M), considering the period of 2003 to 2016.

The maximum and actual evapotranspiration were obtained through the EMBRAPA Climate Guide for the period from 2001 to 2015. The maximum productivity was 127.86 TC/ha identified by M. de A. Silva, Arantes, Rhein, Gava e Kolln (2014), as well as the $K y$ estimated at 1,13 for the sugarcane crop in the Dourados microregion. After identifying the variables, three scenarios were designed (favorable, reasonable and unfavorable) considering the water deficit. Based on the three scenarios, productivity $(87.46 \mathrm{TC} / \mathrm{ha}, 72.95 \mathrm{TC} / \mathrm{ha}$ and $62.69 \mathrm{TC} / \mathrm{ha}$ respectively) was estimated, with the average of the three scenarios being the value of the quantity to be used in the projection of cash flows. It was also considered the breakdown of productivity per cut, taking as reference the study of G. G. de S. Pereira, Albrecht, Fausto e Migliavacca (2015) that consider for the second cut a productivity decrease of $15 \%$ and in other cuts $12 \%$ being the productivity $1^{\text {st }}$ cut $74.37 \mathrm{TC} / \mathrm{ha}, 2^{\text {nd }}$ cut $63.21 \mathrm{TC} / \mathrm{ha}, 3^{\text {rd }}$ cut 55.63 $\mathrm{TC} / \mathrm{ha}, 4^{\text {th }}$ cut $48.95 \mathrm{TC} / \mathrm{ha}$ and $5^{\text {th }}$ cut $43.08 \mathrm{TC} / \mathrm{ha}$, resulting in an estimate of 407,074 tons of sugarcane.

\begin{tabular}{|c|c|}
\hline$T B$ & $\begin{array}{l}\text { Funrural of } 2.85 \% \text { incident on estimated annual revenue ( } \mathrm{R} \$ 28,934,819.92) \text {, } \\
\text { which totaled } \mathrm{R} \$ 824,642.37 \text {. }\end{array}$ \\
\hline$C P P$ & $\begin{array}{l}\text { The projected cost was provided by the entity based on the previous harvest } \\
\text { history, which totals } \mathrm{R} \$ 15,268,140.90 \text {. }\end{array}$ \\
\hline DO & $\begin{array}{l}\text { The projected Operating Expenses were provided by the entity based on } \\
\text { historical harvest, which totals R } \$ 1,068,959.70 \text {. }\end{array}$ \\
\hline$D E_{x}$ & Projected depreciation was provided by the entity and amounts to $\mathrm{R} \$ 3,936,446.64$. \\
\hline$I R$ & $\begin{array}{l}\text { The } 34 \% \text { rate on Earnings Before Interest, Taxes, Depreciation and Amortization } \\
\text { (R \$ 7,836,630.31). }\end{array}$ \\
\hline $\begin{array}{c}\left\{R f_{g}+R_{c}+\beta C_{L G}\left[\beta_{G G}\left(R_{M G}-R f_{g}\right)\right](1\right. \\
\left.\left.-R^{2}\right)\right\}\end{array}$ & $\begin{array}{l}\text { For the } R f_{g} \text { the rate of } 2.95 \% \text { per year was used for the yield of the } 30 \text {-year } \\
\text { Tbonds quoted on } 31 / 01 / 2018 \text {. Regarding Country Risk }\left(R_{c}\right) \text {, the EMBI + Brazil } \\
\text { rate was used for } 229 \text { points, or } 2.29 \% \text { for the } 31 / 01 / 2018 \text {. The country's beta } \\
\text { ( } \beta C_{L G} \text { ) was obtained by regression between the Ibovespa variation and the MSCI } \\
\text { variation ACWI from January } 2013 \text { to January } 2018 \text {, which resulted in an angular } \\
\text { coefficient (slope) of } 1.1803 \text {. As unleveraged beta of comparable companies in } \\
\text { the global market }\left(\beta_{G G}\right) \text {, we used the unlevered beta of the Farming/Agriculture } \\
\text { sector calculated at } 0.56 \text { in January } 2018 \text { by Damodaran }(2018) \text {. As a proxy for } \\
\text { the global market return }\left(R_{M G}\right) \text {, we used the return annual average of the period } \\
2013 \text { to } 2017 \text { of the MSCI ACWI, whose value is } 11.29 \% \text { per year. The } \\
\text { coefficient of determination }\left(R^{2}\right) \text { was calculated from the regression between the } \\
\text { volatility of the Ibovespa versus the variation of the EMBI + Brazil from January } \\
2013 \text { to January } 2018 \text {. The value calculated for the coefficient of determination } \\
\text { from the proposed regression is } 0.279 \text {. }\end{array}$ \\
\hline$k_{d}(1-T)$ & $\begin{array}{l}\text { The company uses debit subsidized by government incentive agribusiness programs } \\
\text { and presents a weighted debit interest rate according to sources of } 10.15 \% \text {. }\end{array}$ \\
\hline$P$ & $\begin{array}{l}\text { The company has an onerous debt of } \mathrm{R} \$ 195,950,000.00 \text {, equivalent to } 48.33 \% \\
\text { of the capital structure. }\end{array}$ \\
\hline$P L$ & $\begin{array}{l}\text { The company has an equity of } \mathrm{R} \$ 209,530,000.00 \text {, equivalent to } 51.67 \% \text { of the } \\
\text { capital structure. }\end{array}$ \\
\hline
\end{tabular}


The fair value of the biological asset was measured using Equation 5 composed of the elements presented in Table 2, as below.

$$
\begin{aligned}
& V A T_{j}=\sum_{j=1}^{\infty} \frac{\left\{\left[\left(\left(\frac{\sum_{n}^{1} P_{n}}{n}\right)\left(\frac{\sum_{n \text { cenarios }}^{1}\left[1-K_{y}\left(1-\frac{E T_{r}}{E T_{m}}\right)\right] Y_{m}}{n \text { cenarios }}\right)\right)-T B-C P P-D O-D E_{x}\right]-I R\right\}+D E_{x}}{\left(1+\left[\left(\left\{R f_{g}+R_{c}+\beta C_{L G}\left[\beta_{G G}\left(R_{M G}-R f_{g}\right)\right]\left(1-R^{2}\right)\right\} \frac{E}{(D+E)}\right)+\left(k_{d}(1-T) \frac{D}{(D+E)}\right)\right]\right)^{j}} \\
& \left\{\left\{\left[71,08\left(\begin{array}{c}
\left\{\left[1-1,13\left(1-\frac{1200,30}{1666,25}\right)\right] 127,86\right\}+\left\{\left[1-1,13\left(1-\frac{1153,83}{1861,17}\right)\right] 127,86\right\}+ \\
{\left[\left[1-1,13\left(1-\frac{1040,38}{1895,22}\right)\right] 127,86\right\}} \\
3
\end{array}\right)\right]\right\}\right\}
\end{aligned}
$$

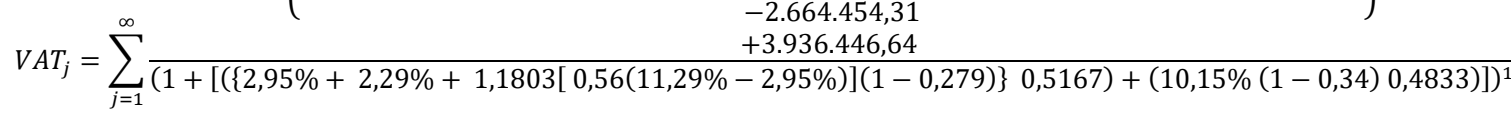

$$
\begin{aligned}
& V T_{j}=\sum_{j=1}^{\infty} \frac{\left.\left[\begin{array}{c}
28.934 .819,92-824.642,37-15.268 .140,90 \\
-1.068 .959,70-3.936 .446,64
\end{array}\right)-2.664 .454,31\right]+3.936 .446,64}{(1+[(0,0921 \times 0,5167)+(0,0670 \times 0,4833)])^{1}} \\
& V T_{j}=\sum_{j=1}^{\infty} \frac{(7.836 .630,31-2.664 .454,31)+3.936 .446,64}{(1+0.08)^{1}} \\
& V A T_{j}=\sum_{j=1}^{\infty} \frac{9.108 .622,65}{(1+0.08)^{1}} \\
& V A T_{j}=R \$ 8.433 .909,86
\end{aligned}
$$

This is the fair value of the biological asset to be recorded in the entity's financial report. The second variable, which represents the projected amount for the period, is determinant in the measurement of biological assets, since it directly affects the projection of revenue. It should be noted that the average of the three scenarios of $74.37 \mathrm{TC} / \mathrm{ha}$ exceeds the historical average of 2010 to 2015 , which totals $71.66 \mathrm{TC} / \mathrm{ha}$, which suggests that the use of the interdisciplinary methodology offers more refined information for accounting.

After the empirical application of the proposed interdisciplinary methodology, it is verified that the aggregation of the agronomic variable to the calculation, brought contributions to the accounting measurement, considering that, when estimating productivity considering the uncertainty base to which agricultural production is subject, suggesting an increase in the reliable representation and quality of the information generated.

\section{Final Considerations}

The valuation of biological assets based on fair value can increase reliability and relevance of accounting information by better reflecting the economic-financial reality of entities, which is the differential of our proposal. Despite the complexity, judgement, accounting decisions and qualifications of the evaluator, the assessments made at level three of the fair value hierarchy represent an adequate 
measure that meets international accounting principles and standards. In the context of IAS 41, an interdisciplinary methodological proposal was here presented to measure the fair value of biological assets without an active market, considering the accounting, economic and agronomic aspects.

Agrometeorological models, such as Doorenbos and Kassam (1979), have great potential to contribute to the valuation of biological assets since these assets are highly responsive to climatic and environmental factors. Agrometeorological models contribute with great precision to cash flow projections, given that climatic and environmental aspects can change the value of biological assets quantitatively and qualitatively. In this sense, agronomic knowledge about crop development and climatic and environmental factors may contribute to accounting estimates and projections. As demonstrated in the application of the methodology, it is evident that different disciplines can integrate an interdisciplinary construction that can increase the accuracy and reliability of the generated information, thus contributing to the scientific and social advance.

Given the difficulties in measuring these assets, we have presented some suggestions for accounting choices and estimates, which may contribute to the accounting practice. Even with the uncertainties of agriculture or of various existing techniques, IAS 41 can safely be applied in disciplines other than accounting, such as economics, finance, and agronomy, to a comprehensive analysis of the value of these assets.

Despite the subjectivity implicit in the measurement of assets, it is believed that the disclosure in Explanatory Notes of the assumptions used in all variables, make the information verifiable, controlling the effects of subjectivity. This view is supported by the study by Gonçalves, Lopes, and Craig (2017) who verified that the fair value of biological assets is relevant, especially in companies with higher levels of disclosure. Therefore, what is proposed is to increase the reliable representation of the biological assets in the financial statements, giving greater emphasis on the quantity variable that is determinant in the measurement of these assets.

It should be emphasized that this work aggregates agronomic science in an exploratory way, therefore, more studies are needed to offer a more integrated structure that supports the evaluator when assessing biological assets. Another important point of interdisciplinarity is that agronomy should provide climatic and environmental information as well as estimates of maximum productivity, observed productivity, evapotranspiration and coefficient of responsiveness to water deficit. It would be of great use to create a national public base where such information could be shared with society. This would contribute to scientific development and to specific rural accounting, which requires investments and information to support decision-making and the development of entities from a broader perspective.

For future research lines, it is suggested to apply and validate the interdisciplinary methodology proposed for a wide variety of crops, such as alfalfa, bananas, beans, cabbage, cotton, peanuts, corn, onions, peas, peppers, sorghum, soybean, spring wheat, beet, sugar cane, sunflower, tomato, watermelon and winter wheat in the context of emerging countries. These crops are suggested because they have the coefficient of response to the water deficit already calculated by Doorenbos and Kassam (1979) in the FAO Bulletin 33. Another interesting contribution is the elaboration of a comparative analysis between the different forms of measurement, discussing the economic impact of each one of them. The interdisciplinary methodology offers an innovative and challenging alternative for accounting professionals by expanding the theoretical and methodological repertoire of accounting studies, offering room for diversity and increasing comprehensiveness of accounting.

\section{References}

Ahrens, T., Becker, A., Burns, J., Chapman, C. S., Granlund, M., Habersam, M., Hansen, A, Khalifa, R., Malmi, T., Mennicken, A., Mikes, A., Panozzo, F., Piber, M., Quattrone, P., \& Scheytt, T. 
(2008). The future of interpretive accounting research - A polyphonic debate. Critical Perspectives on Accounting, 19(6), 840-866. https://doi.org/10.1016/j.cpa.2006.07.005

Argilés-Bosch, J. M., Bladon, J. G., \& Monllau, T. (2009). Fair value versus historical cost valuation for biological asset: Implication for the quality of financial information [Working Paper $\mathrm{n}^{\circ}$ 215], Universitat de Barcelona. Facultat d'Economia i Empresa, Barcelona, Espanha.

Argilés-Bosch, J. M., Miarons, M., Garcia-Blandon, J., Benavente, C., \& Ravenda, D. (2018). Usefulness of fair valuation of biological assets for cash flow prediction. Spanish Journal of Finance and Accounting, 47(2), 157-180. https://doi.org/10.1080/02102412.2017.1389549

Armstrong, C. S., Barth, M. E., Jagolinzer, A. D., \& Riedl, E. J. (2010). Market reaction to the adoption of IFRS in Europe. Accounting Review, 85(1), 31-61. https://doi.org/10.2308/accr.2010.85.1.31

Ashraf, M., \& Foolad, M. R. (2007). Roles of glycine betaine and proline in improving plant abiotic stress resistance. Environmental and Experimental Botany, 59(2), 206-216. https://doi.org/10.1016/j.envexpbot.2005.12.006

Assaf Neto, A. (2017). Valuation: Métricas de valor \& avaliação de empresas (2a ed.). São Paulo: Atlas.

Assaf Neto, A., Lima, F. G., \& Araújo, A. M. P. de (2008). Uma proposta metodológica para o cálculo do custo de capital no Brasil. Revista de Administração, 43(1), 72-83.

Barth, M. E. (2006). Including estimates of the future in today's financial statements. Accounting Horizons, 20(3), 271-285. https://doi.org/10.2308/acch.2006.20.3.271

Barth, M. E., Cram, D. P., \& Nelson, K. K. (2001). Accruals and the prediction of future cash flows. The Accounting Review, 76(1), 27-58. https://doi.org/10.2308/accr.2001.76.1.27

Barth, M. E., Landsman, W. R., \& Lang, M. H. (2008). International accounting standards and accounting quality. Journal of Accounting Research, 46(3), 467-498. https://doi.org/10.1111/j.1475-679X.2008.00287.x

Bohušová, H., Svoboda, P., \& Nerudová, D. (2012). Biological assets reporting: Is the increase in value caused by the biological transformation revenue? Agricultural Economics (Czech Republic), 58(11), 520-532. https://doi.org/10.17221/187/2011-AGRICECON

Brewer, G. D. (1999). The challenges of interdisciplinarity. Policy Sciences, 32(4), 327-337. https://doi.org/10.1023/A:1004706019826

Buanes, A., \& Jentoft, S. (2009). Building bridges: Institutional perspectives on interdisciplinarity. Futures, 41(7), 446-454. https://doi.org/10.1016/j.futures.2009.01.010

Centro de Pesquisas Econômicas da Escola Superior de Agricultura Luiz de Queiroz da Universidade de São Paulo. (n.d.). Etanol. Recuperado em 10 de fevereiro, 2018, de https://www.cepea.esalq.usp.br/br/indicador/etanol.aspx

Chavas, J. P., Chambers, R. G., \& Pope, R. D. (2010). Production economics and farm management: A century of contributions. American Journal of Agricultural Economics, 92(2), 356-375. https://doi.org/10.1093/ajae/aaq004

Chavas, J. P., Kliebenstein, J., \& Crenshaw, T. D. (1985). Modeling dynamic agricultural response. The American Journal of Agricultural Economics, 67(3), 636-646. https://doi.org/10.2307/1241087

Copeland, T., Koller, T., \& Murrin, J. (2002). Avaliação de empresas - Valuation: Calculando e gerenciando o valor das empresas (3a ed.). São Paulo: Makron Books. 
Damodaran, A. (2007). Avaliação de empresas (2a ed.). São Paulo: Pearson Prentice Hall.

Damodaran, A. (2009). Avaliação de investimentos: Ferramentas e técnicas para a determinação do valor de qualquer ativo. Rio de Janeiro: Qualitymark.

Damodaran, A. (2010). Avaliação de investimentos: Ferramentas e técnicas para a determinação do valor de qualquer ativo (2a ed). Rio de Janeiro: Qualitymark.

Damodaran, A. (2018). Betas by sector (US). Retrieved February 10, 2018, from http://pages.stern.nyu.edu/ adamodar/New_Home_Page/datafile/Betas

Dantas, A. A. A., Carvalho, L. G. de, \& Ferreira, E. (2007). Classificação e tendências climáticas em Lavras, MG. Ciência e Agrotecnologia, 31(6), 1862-1866. https://doi.org/10.1590/S141370542007000600039

Davila, T., \& Oyon, D. (2008). Cross-paradigm collaboration and the advancement of management accounting knowledge. Critical Perspectives on Accounting, 19(6), 887-893. https://doi.org/10.1016/j.cpa.2007.03.010

Decreto n. 9.895, de 02 de maio de 2000. (2000). Dispõe sobre o tratamento tributário dispensado às operações com os produtos agrícolas que especifica e dá outras providências. Campo Grande, MS: Secretaria de Estado de Fazenda do Mato Grosso do Sul.

Dias, J. M., Filho, \& Machado, L. H. B. (2017). Abordagens da pesquisa em contabilidade. In A. B. Lopes \& S. de Iudícibus (Orgs.), Teoria Avançada de Contabilidade (2a ed., p. 356). São Paulo: Atlas.

Doorenbos, J., \& Kassam, A. H. (1979). Yield response to water [Working Paper no 33/FAO]. Food and Agriculture Organization of the United Nations - Irrigation and Drainage, Roma, Itália.

Eckel, L., Fortin, S., \& Fisher, K. (2003). The choice of discount rate for external reporting purposes: Considerations for standard setting. Accounting Forum, 27(1), 28-59. https://doi.org/10.1111/1467-6303.00095

Elad, C., \& Herbohn, K. (2011). Implementing fair value accounting in the agricultural sector. Edinburgo: The institute of chartered accountants of Scotland.

Empresa Brasileira de Pesquisa Agropecuária. Guia clima. (n.d.). Leituras e informações. Recuperado em 28 de janeiro, 2018, de https://clima.cpao.embrapa.br/

Fogarty, T. J. (2014). A dream deferred: Interdisciplinary accounting in the US. Accounting, Auditing and Accountability Journal, 27(8), 1265-1270. https://doi.org/10.1108/AAAJ-08-2014-1800

Gonçalves, R., Lopes, P., \& Craig, R. (2017). Value relevance of biological assets under IFRS. Journal of International Accounting, Auditing and Taxation, 29, 118-126. https://doi.org/10.1016/j.intaccaudtax.2017.10.001

Gouvêa, J. R. F., Sentelhas, P. C., Gazzola, S. T., \& Santos, M. C. (2009). Climate changes and technological advances: Impacts on sugarcane productivity in tropical southern Brazil. Scientia Agricola, 66(5), 593-605. https://doi.org/10.1590/S0103-90162009000500003

Hammer, G., Carberry, P., \& Stone, R. (2000). Comparing the value of seasonal climate forecasting systems in managing cropping systems. In G. L. Hammer, N. Nicholls, \& C. Mitchell (Orgs.), Applications of seasonal climate forecasting in agricultural and natural ecosystems (Vol. 21, pp. 183-195). Dordrecht: Springer Netherlands. https://doi.org/10.1007/978-94-015-9351-9

Hansson, B. (1999). Interdisciplinarity: For What Purpose? Policy Sciences, 32(4), 339-343. https://doi.org/10.1023/A:1004718320735 
Hendriksen, E. S., \& Van Breda, M. F. (2015). Teoria da contabilidade (T. de A. Z. Sanvicente, Org.) (17 reimp.). São Paulo: Atlas.

Herbohn, K., \& Herbohn, J. (2006). International accounting standard (IAS) 41: What are the implications for reporting forest assets? Small-scale Forest Economics, Management and Policy, 5(2), 175-189. https://doi.org/10.1007/s11842-006-0009-1

Hinke, J., \& Stárová, M. (2013). Application possibilities and consequences of biological assets and agricultural produce reporting in accordance with IFRS principles in the Czech Republic. Agris On-line Papers in Economics and Informatics, 5(4), 77-89.

Holanda, V. B. (2001). Contabilidade: A cibernética empresarial. Revista Contabilidade \& Finanças USP, 14(25), 42-59. https://doi.org/10.1590/S1519-70772001000100003

Hopwood, A. G. (2008). Changing pressures on the research process: On trying to research in an age when curiosity is not enough. European Accounting Review, 17(1), 87-96. https://doi.org/10.1080/09638180701819998

International Financial Reporting Standards. (2011). IFRS 13 fair value measurement. Retrieved January 10, 2018, from https://www.ifrs.org/issued-standards/list-of-standards/ifrs-13-fair-valuemeasurement/

Iudícibus, S. de (2010). Teoria da contabilidade (10a ed.). São Paulo: Atlas.

Iudícibus, S. de, \& Martins, E. (2007). Uma investigação e uma proposição sobre o conceito e o uso do valor justo. Revista Contabilidade \& Finanças - USP, 18(Edição 30 anos de doutorado), 9-18. https://doi.org/10.1590/S1519-70772007000300002

Kaboosi, K., \& Kaveh, F. (2010). Sensitivity analysis of Doorenbos and Kassam (1979) crop water production function. African Journal of Agricultural Research, 5(17), 2399-2417.

Kallapur, S., \& Kwan, S. Y. S. (2004). The value relevance and reliability of brand assets recognized by U.K. firms. The Accounting Review, 79(1), 151-172. https://doi.org/10.2308/accr.2004.79.1.151

Lipe, R. C. (2002). Fair valuing debt turns deteriorating credit quality into positive signals for Boston chicken. Accounting Horizons, 16(2), 169-181. https://doi.org/10.2308/acch.2002.16.2.169

Lopes, A. B., Galdi, F. C., \& Lima, I. S. (2011). Manual de contabilidade e tributação de instrumentos financeiros e derivativos (2a ed.). São Paulo: Atlas.

Malsch, B., \& Guénin-Paracini, H. (2013). The moral potential of individualism and instrumental reason in accounting research. Critical Perspectives on Accounting, 24(1), 74-82. https://doi.org/10.1016/j.cpa.2012.01.005

Marin, F. R., Lopes-Assad, M. L., Assad, E. D., Vian, C. E., \& Santos, M. C. (2008). Sugarcane crop efficiency in two growing seasons in São Paulo state, Brazil. Pesquisa Agropecuaria Brasileira, 43(11), 1449-1455. https://doi.org/10.1590/S0100-204X2008001100002

Marin, F. R., Sentelhas, P. C., \& Ungaro, M. R. G. (2000). Perda de rendimento potencial da cultura do girassol por deficiência hídrica, no Estado de São Paulo. Scientia Agricola, 57(1), 1-6. https://doi.org/10.1590/S0103-90162000000100002

Martelanc, R., Pasin, R., \& Pereira, F. (2010). Avaliação de empresas: Um guia para fusões \& aquisições e private equity. São Paulo: Pearson Prentice Hall. 
Martins, V. A. (2002). Contribuição à avaliação do goodwill: Depósitos estáveis, um ativo intangível. (Dissertação de mestrado). Universidade de São Paulo, Faculdade de Economia, Administração e Contabilidade, São Paulo, SP, Brasil.

Miller, J. P. (2002). O milênio da inteligência competitiva. Porto Alegre: Bookman.

Monteiro, J. E. B. A. (Org.) (2009). Agrometeorologia dos cultivos: O fator meteorológico na produção agrícola. Brasília: Instituto Nacional de Meteorologia.

Morin, E. (2007). Introdução ao pensamento complexo. Lisboa: Instituto Piaget.

Most, K. S. (1977). Accounting theory. Columbus: Grid.

Oliveira, R. A., Santos, R. S., Ribeiro, A., Zolnier, S., \& Barbosa, M. H. P. (2012). Estimativa da produtividade da cana-de-açúcar para as principais regiões produtoras de Minas Gerais usandose o método ZAE. Revista Brasileira de Engenharia Agrícola e Ambiental, 16(5), 549-557. https://doi.org/10.1590/S1415-43662012000500011

Parker, L. D. (2012). Qualitative management accounting research: Assessing deliverables and relevance. Critical Perspectives on Accounting, 23(1), 54-70. https://doi.org/10.1016/j.cpa.2011.06.002

Pegorare, A. B., Fedatto, E., Pereira, S. B., Souza, L. C. F., \& Fietz, C. R. (2009). Irrigação suplementar no ciclo do milho "safrinha" sob plantio direto. Revista Brasileira de Engenharia Agrícola e Ambiental, 13(3), 262-271. https://doi.org/10.1590/S1415-43662009000300007

Pereira, A. R. (2005). Simplificando o balanço hídrico de Thornthwaite-Mather. Bragantia, 64(2), 311 313. https://doi.org/10.1590/S0006-87052005000200019

Pereira, A. R., Angelocci, L. R., \& Sentelhas, P. C. (2002). Agrometeorologia: Fundamentos e aplicações práticas. Guaíba: Ed. Agropecuária.

Pereira, A. R., Sediyama, G. C., \& Villa Nova, N. A. (1997). Evapo(transpi)ração. Piracicaba: FEALQ.

Pereira, G. G. de S., Albrecht, A. J. P., Fausto, D. A., \& Migliavacca, R. A. (2015). Custo de produção de cana-de-açúcar no estado do Mato Grosso do Sul. Revista iPecege, 1(1), 81-102. https://doi.org/10.22167/r.ipecege.2015.1.81

Pereiro, L. E. (2001). The valuation of closely-held companies in Latin America. Emerging Markets Review, 2(4), 330-370. https://doi.org/10.1016/S1566-0141(01)00024-3

Poon, W. W. (2004). Using fair value accounting for financial instruments. American Business Review, 22(1), 30-41.

Póvoa, A. (2007). Valuation: Como precificar ações (2a ed.). São Paulo: Globo.

Rathke, A. A. T., Santana, V. de F., Lourenço, I. M. E. C., \& Dalmácio, F. Z. (2016). International financial reporting standards and earnings management in Latin America. Revista de Administração Contemporânea, 20(3), 368-388. Retrieved from http://www.scielo.br/pdf/rac/v20n3/1415-6555-rac-20-03-00368.pdf. https://doi.org/10.1590/1982-7849rac2016140035

Rech, I. J., \& Oliveira, K. G. de (2011). Análise da aplicação da CPC 29 e IAS 41 aos ativos biológicos no setor de silvicultura. Anais do Congresso da Associação Nacional de Programas de Pósgraduação em Ciências Contábeis, Vitória, ES, Brasil, 5. 
Ribeiro, D. T. O. (2013). Uma contribuição para mensuração dos ativos biológicos e produto agrícola sem mercado ativo e seus reflexos contábeis (Dissertação de Mestrado). Pontifícia Universidade Católica de São Paulo, Departamento de Ciências Contábeis e Atuariais, São Paulo, SP, Brasil.

Rosa, V. G. C., Moreira, M. A., Rudorff, B. F. T., \& Adami, M. (2010). Estimativa da produtividade de café com base em um modelo agrometeorológico-espectral. Pesquisa Agropecuária Brasileira, 45(12), 1478-1488. https://doi.org/10.1590/S0100-204X2010001200020

Roslender, R., \& Dillard, J. F. (2003). Reflections on the interdisciplinary perspectives on accounting project. Critical Perspectives on Accounting, 14(3), 325-351. https://doi.org/10.1006/cpac.2002.0526

Ross, S. A., Westerfield, R. W., \& Jaffe, J. F. (2002). Administração financeira (2a ed., A. Z. Sanvicente, Trad.). São Paulo: Atlas. (Obra original publicada em 1997)

Santos, A. F. dos, Gomes, B. K. C. da S., Brito, E. de, Gaio, L. E., \& Furlan, P. V. D. (2015). Análise da hierarquia do valor justo na mensuração de ativos biológicos das empresas listadas na BM\&BOVESPA no ano de 2013. Anais do Congresso USP Iniciação Científica em Contabilidade. São Paulo, SP, Brasil, 12.

Secretaria de Estado de Meio Ambiente e Desenvolvimento Econômico do Mato Grosso do Sul (n.d.). Base de dados do estado. Recuperado em 21 de fevereiro, 2018, de http://bdeweb.semade.ms.gov.br/bdeweb/

Silva, L. L., Costa, R. F., Campos, J. H. B. da C., \& Dantas, R. T. (2009). Influência das precipitações na produtividade agrícola no Estado da Paraíba. Revista Brasileira de Engenharia Agrícola e Ambiental, 13(4), 454-461. https://doi.org/10.1590/S1415-43662009000400013

Silva, M. de A., Arantes, M. T., Rhein, A. F. de L., Gava, G. J. C., \& Kolln, O. T. (2014). Potencial produtivo da cana-de-açúcar sob irrigação por gotejamento em função de variedades e ciclos. Revista Brasileira de Engenharia Agrícola e Ambiental, 18(3), 241-249. https://doi.org/10.1590/S1415-43662014000300001

Silva, R. L. M. da, Nardi, P. C. C., \& Ribeiro, M. de S. (2015). Gerenciamento de resultados e valorização dos ativos biológicos. Brazilian Business Review, 12(4), 1-27. https://doi.org/10.15728/bbr.2015.12.4.1

Silva, S. A., Lima, J. S. S., \& Oliveira, R. B. (2011). Modelo agrometeorológico na estimativa da produtividade de duas variedades de café arábica considerando a variabilidade espacial. Irriga $\begin{array}{lllll}\text { Brazilian Journal of Irrigation and Drainage, } & 16(1),\end{array}$ https://doi.org/10.15809/irriga.2011v16n1p01

Sivakumar, M. V. K., Gommes, R., \& Baier, W. (2000). Agrometeorology and sustainable agriculture. Agricultural and Forest Meteorology, 103(1/2), 11-26. https://doi.org/10.1016/S01681923(00)00115-5

Stember, M. (1991). Advancing the social sciences throught he interdisciplinary enterprise. The Social Science Journal, 28(1), 1-14. https://doi.org/10.1016/0362-3319(91)90040-B

Svoboda, P., \& Bohušová, H. (2017). Amendments to IAS 16 and IAS 41: Are there any differences between plant and animal from a financial reporting point of view? Acta Universitatis Agriculturae et Silviculturae Mendelianae Brunensis, 65(1), 327-337. https://doi.org/10.11118/actaun201765010327

Teixeira, V. P. M., \& Cunha, M. F. da (2017). Aplicabilidade dos modelos CAPM local, CAPM local ajustado e CAPM ajustado híbrido ao mercado brasileiro. Anais do Congresso USP de Iniciação Científica em Contabilidade. São Paulo, SP, Brasil,14. 
Thornthwaite, C. W., \& Mather, J. R. (1955). The water balance. Centerton: Drexel Institute of Technology - Laboratory of Climatology.

Walker, S. P. (2005). The academy of accounting historians. Accounting Historians Journal, 32(2), $233-$ 259. https://doi.org/10.1177/1032373209335304

Watts, R. L. (2003). Conservatism in accounting part I: Explanations and implications. Accounting Horizons, 17(3), 207-221. https://doi.org/10.2308/acch.2003.17.3.207

Yang, Z., Rohrbach, K., \& Chen, S. (2005). The impact of standard setting on relevance and reliability of accounting information: Lower of cost or market accounting reforms in China. Journal of International Financial Management and Accounting, 16(3), 194-228. https://doi.org/10.1111/j.1467-646X.2005.00117.x

\author{
Authors \\ Rafael Todescato Cavalheiro \\ Rodovia Dourados-Itahum, Km 12, Caixa Postal 364, 79804-970, Dourados, MS, Brasil \\ E-mail address: rafaeltodescato@hotmail.com \\ Régio Marcio Toesca Gimenes \\ Rodovia Dourados-Itahum, Km 12, Caixa Postal 364, 79804-970, Dourados, MS, Brasil \\ E-mail address: regiomtoesca@gmail.com, regiogimenes@ufgd.edu.br \\ Erlaine Binotto \\ Rodovia Dourados-Itahum, Km 12, Caixa Postal 364, 79804-970, Dourados, MS, Brasil \\ E-mail address: e-binotto@uol.com.br, erlainebinotto@ufgd.edu.br \\ Carlos Ricardo Fietz \\ Rodovia BR 163, Km 253,6, Caixa Postal 449, Zona Rural, 79804-970, Dourados, MS, Brasil \\ E-mail address: carlos.fietz@embrapa.br
}

\title{
Contributions
}

1st author: Research design, theoretical and methodological development, application, writing and final revision.

2nd author: Research design, theoretical and methodological development, application, writing and final revision.

3rd author: Research design, theoretical and methodological development, application, writing and final revision. 4th author: Research design, theoretical and methodological development, application, writing and final revision.

\section{Funding}

The authors reported that there is no financial support for the research in this article.

\section{Conflict of Interest}

The authors have stated that there is no conflict of interest.

\section{Plagiarism Check}

The RAC maintains the practice of submitting all documents approved for publication to the plagiarism check, using specific tools, e.g.: iThenticate. 